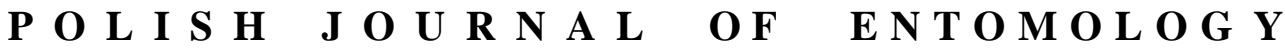

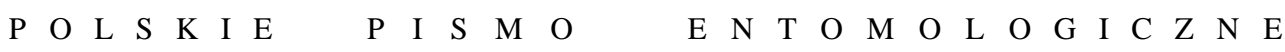

VOL. 83: 121-129

Lublin

30 June 2014

DOI: $10.2478 /$ pjen-2014-0009

\section{Distribution and molecular identification of Tuta absoluta (MEYRICK, 1917) (Lepidoptera, Gelechiidae) populations in Bosnia and Herzegovina and Montenegro}

\author{
ZORICA ĐURIĆ ${ }^{1}$, DUŠKA DELIĆ ${ }^{1}$, SNJEŽANA HRNČIĆ ${ }^{2}$, SANJA RADONJIĆ ${ }^{2}$ \\ ${ }^{1}$ Faculty of Agriculture Banja Luka, University of Banja Luka, Bul. vojvode Petra Bojovića \\ 1a, 78000 Banja Luka, Bosnia and Herzegovina, e-mail: zorica.djuric@agrofabl.org, \\ duska.delic@agrofabl.org \\ ${ }^{2}$ Biotechnical Faculty Podgorica, University of Montenegro, Mihajla Lalića 1, 81000 \\ Podgorica, Montenegro,e-mail: hrncic@t-com.me,sanja_radonjic@t-com.me
}

\begin{abstract}
Since 2010, the South American tomato moth - Tuta absoluta (MEYRICK, 1917) (Lepidoptera, Gelechiidae) - has been recorded in Bosnia and Herzegovina (B\&H) and Montenegro. In 2012, pheromone traps were placed among tomato crops growing in greenhouses and open fields in 14 localities in B\&H and Montenegro; the pest was caught at all the sites. Adults were caught in both greenhouses and open fields in Trebinje (B\&H) on $4^{\text {th }}$ June 2012 and in Ulcinj (Montenegro) in mid-May. Species identification was confirmed by means of morphological characters of adults and male genitalia. In addition, molecular identification of specimens from $\mathrm{B} \& \mathrm{H}$ and Montenegro was performed using mitochondrial (mtDNA) markers.
\end{abstract}

KEY WORDS: South American tomato moth, pheromone trapping, molecular identification, COI.

\section{INTRODUCTION}

The South American tomato moth - Tuta absoluta (MEYRICK, 1917) (Lepidoptera, Gelechiidae) - is one of the most devastating pests of tomatoes, both in greenhouse and open field locations in South America, Europe and North Africa (in the Sahel savannah) (DESNEUX et al. 2010). It has also been reported to attack potatoes (Solanum tuberosum L.), eggplants (Solanum melongena L.), peppers (Capsicum annum L.), weeds (Datura 
stramonium L., Nicotiana glauca G.) (KORYCINSKA \& MORAN 2009) and green beans (Phaseolus vulgaris L.) (EPPO 2009).

T. absoluta is originally from South America and was first described in Peru in 1917 as Phthorimaea absoluta (MEYRICK, 1917) (DESNEUX et al. 2010). This has other synonyms: Scrobipalpuloides absoluta (PovolnY, 1987), Scrobipalpula absoluta (PovOLNY, 1964) and Gnorimoschema absoluta (CLARKE, 1962) (EPPO 2005).

In Europe, the first record was in Spain in 2006 (EPPO 2008a), followed by other Mediterranean countries: Tunisia (EPPO 2009d), Algeria (GUENAOUI 2008, cited in OSTRAUSKAS \& IVINSKIS 2010), Morocco (EPPO 2008b), France (EPPO 2009a), Italy (EPPO 2009b), Portugal (EPPO 2009g), Malta (EPPO 2009h) and Albania (EPPO 2009f). Its prevalence and distribution has continued in Europe and the presence of T. absoluta was also recorded in the countries of the former Yugoslavia: in Slovenia (KNAPIČ \& MAROLT 2009, cited in OSTRAUSKAS \& IVINSKIS 2010); Croatia (GOTLIN ČULJAK et al. 2010), where the pest was found in coastal areas and sporadically in inland parts of the country (ŠIMALA pers. comm., cited in ŠKALJAC et al. 2012); then in Kosovo (EPPO 2010d), Serbia (TOŠEVSKI et al. 2011) and Montenegro (HRNČIĆ \& RADONJIĆ 2011). In Bosnia and Herzegovina, its presence was confirmed for the first time in 2010, at Čapljina (West Herzegovina, Bosnia and Herzegovina) (OsTOJIĆ 2010) and in Banja Luka (Republic of Srpska, Bosnia and Herzegovina) (ĐURIĆ \& HRNČIĆ 2010).

T. absoluta spreads mostly from one tomato plant to another while these are being planted, and from one region to another as a result of the trans-border trade (import/export) in tomatoes (TOŠEVSKI et al. 2011, VAN DEVENTER 2009, cited in BETTAIBI et al. 2012). It has also been observed that adults can cover a few kilometres by flying (VAN DEVENTER 2009, cited in BETTAIBI et al. 2012) and in a year can often be carried more than $1000 \mathrm{~km}$ on the wind (LEVY 2010).

T. absoluta is a serious threat to tomato production, as it can decrease fruit quality and result in 50 to 100\% yield losses (EPPO 2005, VIGGNIANI et al 2009, DESNEUX et al. 2010). The larvae destroy tomato plants by mining the leaves, stems and buds, and by burrowing tunnels in the fruits, thereby rendering fresh tomatoes unmarketable (VIGGNIANI et al. 2009).

This pest is of great economic importance and has spread to other regions of Europe. The distribution, as well as the morphological and molecular identification of T. absoluta populations in B\&H and Montenegro, has been studied.

\section{Acknowledgements}

The authors appreciate the recognition and funding support received from the Ministry of Science and Technology of Republika Srpska and Ministry of Science of Montenegro. 


\section{MATERIALS AND METHODS}

\section{Survey and pheromone trapping}

The survey was conducted from May to October 2012, in the main tomato production areas of Republic of Srpska (B\&H) and Montenegro. A total of 14 localities (Table 1, Fig. 1) -7 each in $\mathrm{B} \& \mathrm{H}$ and Montenegro - were selected for the survey.

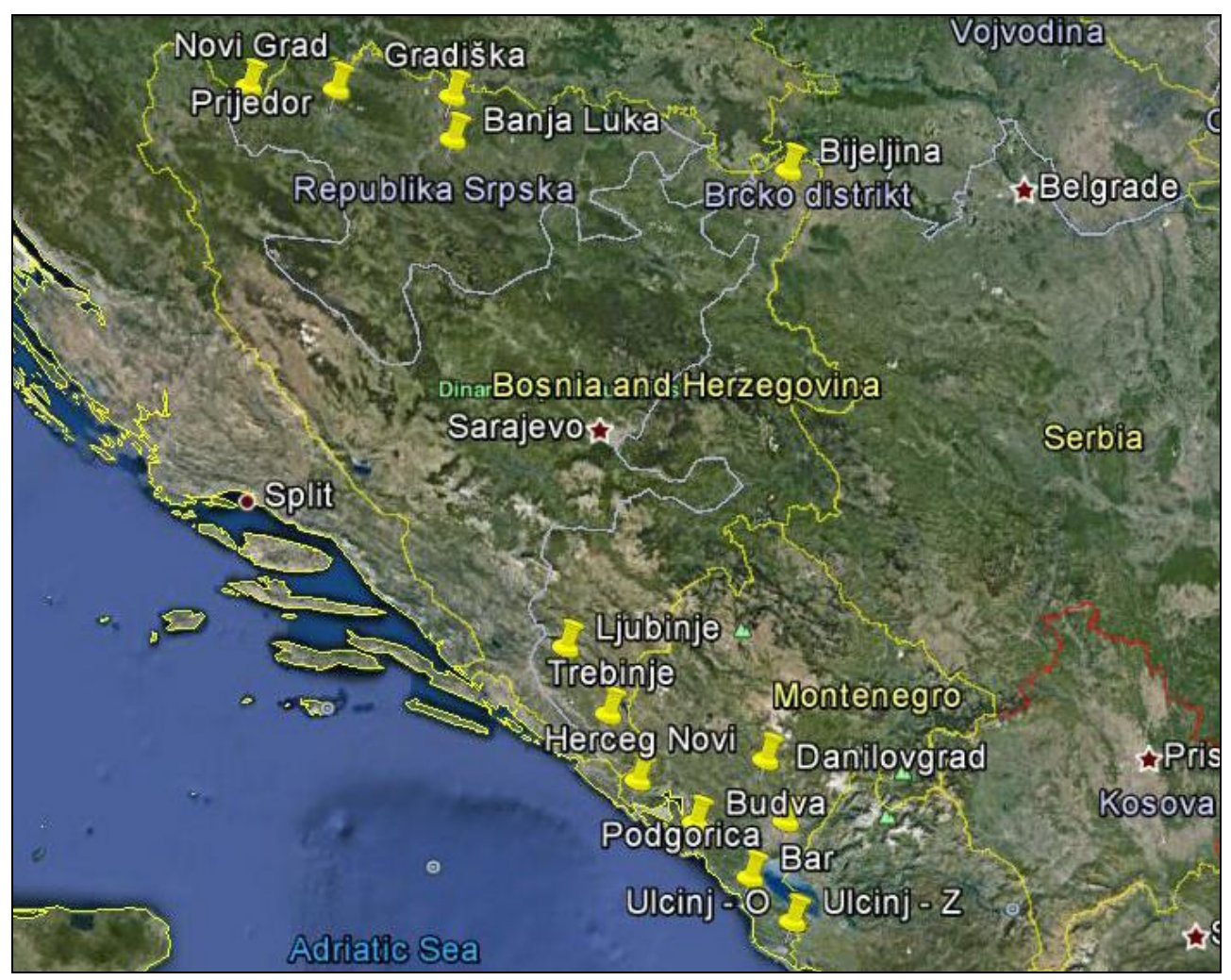

Fig. 1. Map showing the localities surveyed in Bosnia and Herzegovina and Montenegro.

Csalomon ${ }^{\circledR}$ pheromone traps were used as an early detection tool for T. absoluta. One trap per site was placed inside greenhouses or in open fields, depending on where the tomato crops were growing. They were hung $20 \mathrm{~cm}$ above the plant, checked and moved up once every 2 weeks, while pheromone plugs were replaced every 6 weeks. Sticky trap bottoms were changed as needed. Identification of the species was confirmed using the morphological characters of adults and the male genitalia. For this purpose, adults were 
obtained from infested tomato leaves collected from surveyed sites. Additionally, live specimens, collected directly from tomato plants using a pooter, were preserved in $96 \%$ ethanol and submitted for further molecular identification.

Table 1. Overview of the localities surveyed.

\begin{tabular}{|c|c|c|c|}
\hline Locality & Country & GPS coordinate & $\begin{array}{l}\text { Tomato crop } \\
\text { production }\end{array}$ \\
\hline Banja Luka & Bosnia and Herzegovina & $44^{\circ} 50^{\prime} 01.8^{\prime \prime} \mathrm{N}, 17^{\circ} 22^{\prime} 00.2^{\prime \prime} \mathrm{E}$ & greenhouse \\
\hline Prijedor & Bosnia and Herzegovina & $44^{\circ} 59^{\prime} 48.1^{\prime \prime} \mathrm{N}, 16^{\circ} 43^{\prime} 48.2^{\prime \prime} \mathrm{E}$ & greenhouse \\
\hline Novi Grad & Bosnia and Herzegovina & $44^{\circ} 59^{\prime} 13.4^{\prime \prime} \mathrm{N}, 16^{\circ} 15^{\prime} 42.8^{\prime \prime} \mathrm{E}$ & open field \\
\hline Gradiška & Bosnia and Herzegovina & $44^{\circ} 59^{\prime} 53.0^{\prime \prime} \mathrm{N}, 17^{\circ} 20^{\prime} 59.8^{\prime \prime} \mathrm{E}$ & greenhouse \\
\hline Bijeljina & Bosnia and Herzegovina & $44^{\circ} 46^{\prime} 44.1^{\prime \prime} \mathrm{N}, 19^{\circ} 09^{\prime} 35.5^{\prime \prime} \mathrm{E}$ & greenhouse \\
\hline Trebinje & Bosnia and Herzegovina & $42^{\circ} 42^{\prime} 07.1^{\prime \prime} \mathrm{N}, 18^{\circ} 19^{\prime} 56.3^{\prime \prime} \mathrm{E}$ & open field \\
\hline Ljubinje & Bosnia and Herzegovina & $42^{\circ} 56^{\prime} 44.2^{\prime \prime} \mathrm{N}, 18^{\circ} 05^{\prime} 49.5^{\prime \prime} \mathrm{E}$ & greenhouse \\
\hline Podgorica & Montenegro & $42^{\circ} 19^{\prime} 25.0^{\prime \prime} \mathrm{N}, 19^{\circ} 15^{\prime} 48.0^{\prime \prime} \mathrm{E}$ & open field \\
\hline Danilovgrad & Montenegro & $42^{\circ} 33^{\prime} 12.0^{\prime \prime} \mathrm{N}, 19^{\circ} 08^{\prime} 53.0^{\prime \prime} \mathrm{E}$ & greenhouse \\
\hline Herceg Novi & Montenegro & $42^{\circ} 27^{\prime} 25.0^{\prime \prime} \mathrm{N}, 18^{\circ} 29^{\prime} 55.0^{\prime \prime} \mathrm{E}$ & greenhouse \\
\hline Budva & Montenegro & $42^{\circ} 18^{\prime} 24.0^{\prime \prime} \mathrm{N}, 18^{\circ} 48^{\prime} 09.0^{\prime \prime} \mathrm{E}$ & open field \\
\hline Bar & Montenegro & $42^{\circ} 06^{\prime} 22.0^{\prime \prime} \mathrm{N}, 19^{\circ} 05^{\prime} 37.0^{\prime \prime} \mathrm{E}$ & greenhouse \\
\hline Ulcinj & Montenegro & $41^{\circ} 56^{\prime} 44.0^{\prime \prime} \mathrm{N}, 19^{\circ} 19^{\prime} 44.0^{\prime \prime} \mathrm{E}$ & open field \\
\hline Ulcinj & Montenegro & $41^{\circ} 56^{\prime} 41.0^{\prime \prime} \mathrm{N}, 19^{\circ} 19^{\prime} 03.0^{\prime \prime} \mathrm{E}$ & greenhouse \\
\hline
\end{tabular}

\section{Morphological identification}

Adults obtained from infested tomato leaves collected from the survey sites were analysed at the entomology laboratory under a stereomicroscope. Also, a certain number of adults were preserved in $96 \%$ ethanol for further study.

Selected specimens were macerated, after which the male genitalia were extracted and examined. All adults caught were identified to species level, according to the keys and descriptions presented by different authors (EPPO 2005, KORYCINSKA \& MORAN 2009, USDA 2011). Identification of T. absoluta was based on morphological characters of adults, as well as on the shape of the uncus, digitate, setose valvae and the well-developed vinculum and phallus of the male genitalia.

\section{DNA extraction}

Genomic DNA was extracted from two adult abdomens (two individuals from each location monitored; Table 1) using DNeasy Blood and Tissue Kit (QIAGEN), following the manufacturer's instructions. In total, 14 samples were submitted for DNA extraction procedure and PCR analyses. 


\section{PCR analyses}

The mitochondrial cytochrome oxidase subunit I (COI) gene proved suitable for PCR because of its good genetic resolution, which is ideal for differentiation at the species level (KAMBHAMPATI \& SMITH 1995). Therefore, primers amplifying mtCOI fragments were employed for the PCR analyses.

Amplification of the COI gene 5'-end was performed with LCO1490 and HCO2198 primers (FOLMER et al. 1994), while the COI gene 3'-end was amplified using C1-J-2195 and L2-N-3014 primer pairs (SIMON et al. 1994) (Table 2). PCR was set up in $20 \mu \mathrm{L}$ final volume and the master mix contained: High Yield Reaction Buffer A with $\mathrm{Mg}(1 \mathrm{x}), 2.25$ $\mathrm{mM} \mathrm{MgCl} 2,0.6 \mathrm{mM}$ of each dNTP, $0.5 \mu \mathrm{M}$ of each primer and $0.1 \mathrm{U} / \mu$ of KAPATaq DNA polymerase (Kapabiosystems). Amplification was performed in a Thermal Cycler 2720 (Applied Biosystems) and the temperature profile for the amplification in the reaction with LCO1490/HCO2198 primers was: $5 \mathrm{~min}$. at $95{ }^{\circ} \mathrm{C}$ (initial denaturation) followed by $1 \mathrm{~min}$. at $95{ }^{\circ} \mathrm{C}, 1 \mathrm{~min}$. at $54{ }^{\circ} \mathrm{C}, 1 \mathrm{~min}$. and $30 \mathrm{sec}$. at $72{ }^{\circ} \mathrm{C}$ for $35 \mathrm{cycles}$, with a final extension for $7 \mathrm{~min}$. at $72{ }^{\circ} \mathrm{C}$. The amplification protocol with C1-J-2195/L2-N-3014 primer pair was distinguished by the annealing temperature $\left(45^{\circ} \mathrm{C}\right)$ and the number of cycles $(40)$.

The PCR products were visualised after running $1 \%$ agarose gel $(100 \mathrm{~V})$ for 1 hour. The gel was stained with a $0.05 \%$ solution of ethidium bromide.

Table 2. Sequences of oligonucleotide primers used in PCR analyses.

\begin{tabular}{|l|l|}
\hline \multicolumn{1}{|c|}{ Primer sequence (5'-3') } & \multicolumn{1}{|c|}{ Reference } \\
\hline COI gene 5'-end (709 bp) & FOLMER et al. (1994) \\
LCO1490: GGTCAACAAATCATAAAGATATTGG & \\
HCO2198: TAAACTTCAGGCTGACCAAAAAATCA & \\
\hline COI gene 3-end (864 bp) & SIMON et al. (1994) \\
C1-J-2195: TTGATTTTTTGGTCATCCAGAAGT & \\
L2-N-3014: TCCAATGCACTAATCTGCCATATTA & \\
\hline
\end{tabular}

\section{Sequencing and sequence analyses}

PCR products of DNA samples from Bijeljina $(\mathrm{B} \& \mathrm{H})$ and Ulcinj (Montenegro) were subjected to sequencing and sequence analyses. The Bijeljina $(\mathrm{B} \& \mathrm{H})$ and Ulcinj (Montenegro) populations of $T$. absoluta are geographically and climatically distinct (Fig. 1), so they were selected for further analysis.

Selected PCR products were purified using the QIAquick PCR purification Kit (QIAGEN) following the manufacturer's instructions and sent to Macrogen (the Netherlands) for sequencing. BLAST analysis (Basic Local Alignment Search Tool; http://blast.ncbi.nlm.nih.gov/Blast.cgi) was used to compare the sequences obtained with those from the GenBank. 


\section{RESULTS AND DISCUSSION}

\section{Distribution and pheromone trapping}

The presence of T. absoluta was confirmed for the first time in 2010 in Bosnia and Herzegovina (ĐURIĆ \& HRNČIĆ 2010, OSTOJIĆ 2010) and in Montenegro (HRNČIĆ \& RADONJIĆ 2011).

In order to determine the distribution of the pest, pheromone traps were placed at 14 localities in B\&H and Montenegro in May 2012 (Table 1, Fig. 1). At all the localities surveyed, T. absoluta was caught from May to October 2012. Records show that the first adults in B\&H were caught in Trebinje on $4^{\text {th }} \mathrm{June}$, Ljubinje on $14^{\text {th }} \mathrm{June}$, Bijeljina on $27^{\text {th }}$ June, Novi Grad on $18^{\text {th }}$ August, Banja Luka on $11^{\text {th }}$ September, Prijedor on $12^{\text {th }}$ September and Gradiška on $7^{\text {th }}$ October. In comparison with the study in B\&H during 2010 and 2011 (ĐURIĆ et al. 2012), this survey confirmed the presence of T. absoluta at the Novi Grad, Prijedor and Gradiška localities for the first time.

The first adults in Montenegro were caught in mid-May in the Ulcinj locality, both in greenhouses and open fields, in Herceg Novi at the end of May, and in the other localities from $1^{\text {st }}$ to $5^{\text {th }}$ June.

The results of this survey show that in Montenegro and in the southern parts of B\&H, where a Mediterranean climate prevails, the first adults were trapped earlier than in northern B\&H, which has a continental climate (Fig. 1). This can be explained by the fact that $T$. absoluta prefers areas with a warmer climate, because it is a native of South America and also because its spread through Europe started in the Mediterranean region (DESNEUX et al. 2010). On the other hand, this survey confirmed that the pest is also present in greenhouses and open fields in the continental climate of B\&H, such as in Bijeljina, Novi Grad, Banja Luka, Prijedor and Gradiška. In accordance with many authors (VAN DEVENTER 2009, cited in BETTAIBI et al. 2012, ToŠEvSKI et al. 2011, Đurić et al. 2012), this is partly caused by the intensive tomato production in some areas, as well as the cross-border tomato trade in the country.

\section{Molecular identification}

The main aim of the present work was to identify the presence, and estimate adult emergence and distribution of $T$. absoluta specimens in different localities in the two countries. In addition to morphological identification, molecular tools such as PCR, sequencing and sequence analyses were also employed for $T$. absoluta identification, and mitochondrial markers were used for the analyses.

Both COI gene fragments were successfully amplified in all 14 DNA samples. Amplified PCR products from populations from two climatically and geographically distinct locations (Bijeljina/B\&H and Ulcinj/Montenegro) (Fig. 1) were sequenced. 
Sequences were obtained from GenBank under accession numbers: KC852871 (B\&H), KC852872 (Montenegro) (5'COI) and KC852869 (B\&H), KC852870 (Montenegro) (3'COI). No polymorphism was observed when PCR products from mixed DNA samples were sequenced.

No difference was observed in the BLAST analyses of 5' $\mathrm{COI}$ sequences from B\&H and Montenegro, as they were 100\% identical. The BLAST analyses also revealed that they were $100 \%$ identical with those from Serbia (GenBank Acc.No. JN417242) (ToŠEVSKI et al. 2011) and Tunisia (GenBank Acc.No. JQ749676).

Comparing the sequenced 3 ' COI fragments, we discovered that the $\mathrm{B} \& \mathrm{H}$ and Montenegro sequences were $99 \%$ identical. The B\&H sequence revealed a $100 \%$ identity with T. absoluta specimens collected from Murcia-Spain (HQ873080), Crete-Greece (HQ873053) and Turin-Italy (HQ873049) (CIFUENTES et al. 2009). In contrast to this, the Montenegro 3' COI fragment sequence was confirmed to have $100 \%$ similarity with T. absoluta sequences from Chile (HQ873062), Sicily-Italy (HQ873048), Turin-Italy (HQ873050), Andalusia-Spain (HQ873076), Izmir-Turkey (HQ873051) and Argentina (HQ873057) (CIFUENTES et al. 2009).

Although it focused primarily on the identification of T. absoluta, this work was also designed to analyse the variability of $T$. absoluta populations in different regions, including different markers, by employing different molecular methods. Mitochondrial markers have frequently been used to study the genetic variability of many invasive insect species (KAmbHampti \& SMith 1995). However, Cifuentes et al. (2009) studied the genetic variability of $T$. absoluta from the Mediterranean and South American populations. They used mitochondrial and ribosomal markers, and the results of the phylogenetic analysis show that no genetic variability was found between the Mediterranean and South American populations. Therefore, other molecular markers and methods should be used for studying variability in T. absoluta populations. For example, RAPD-PCR was used to examine the genetic variability of the Tunisian population (BETTAIBI et al. 2012): the results revealed a high genetic variability among the 7 populations tested. Using AFLP, the Brazilian population of $T$. absoluta was separated into two groups according to resistance to insecticides (SUINAGA et al. 2004). In view of this, future projects should make use of other markers and molecular methods, which will enable a comprehensive study of the variability of the T. absoluta populations in B\&H and Montenegro.

\section{Conclusions}

T. absoluta is a major threat to tomato production. It was detected in $\mathrm{B} \& \mathrm{H}$ and Montenegro in 2010. Since then, it has spread within both countries and in all 14 localities surveyed during this study. Pheromone traps have been shown to be a very useful tool for the early detection of this pest. 
This morphological and molecular study confirms that the pest spread rapidly through both countries and adapted to continental climate conditions.

However, other markers and molecular methods could be used in future studies. These would provide a clearer insight into the dispersal mode, phylogenetic structure and insecticide resistance mechanisms of $T$. absoluta, which is crucial for developing an effective pest management strategy.

\section{REFERENCES}

Bettaibi A., Mezghani-Khemakhem M., Bouktila D., Makni H., Makni M. 2012. Genetic variability of the Tomato Leaf Miner (Tuta absoluta MEYRICK; Lepidoptera: Gelechiidae) in Tunisia, inferred from RAPD-PCR. Chilean Journal of Agricultural Research 72(2): 212-216.

Cifuentes D., Chynoweth R., Bielza P. 2011. Genetic study of Mediterranean and South American populations of tomato leafminer Tuta absoluta (PovOLNY, 1994) (Lepidoptera: Gelechiidae) using ribosomal and mitochondrial markers. Pest Management Science 67(9): 1155-1162.

Desneux N., Wajnberg E., Wyckhuys K.A.G., Burgio G., Arpaia S., Narvaez-Vasquez C.A., Gonzalez-Cabrera J., Catalan Ruescas D., Tabone E., Frandon J., Pizzol J., Poncet C., CABello T., Urbaneja A. 2010. Biological invasion of European tomato crops by Tuta absoluta: ecology, geographic expansion and prospects for biological control. Journal of Pest Science 83(3): 197-215.

Đurić Z., HrnčIĆ S. 2010. Tomato leaf miner - Tuta absoluta MEYRICK in Republic of Srpska. Agroznanje Journal 11(3): 17-23. (in Serbian)

Đurić Z., HrnčIĆ S., VujanoviĆ M., Đurić B., MitriĆ S. 2012. Tuta absoluta (MeYriCK) (Lepidoptera, Gelechiidae) in the Republic of Srpska (Bosnia and Herzegovina). EPPO Bulletin 42(2): 337-340.

EPPO 2005. Tuta absoluta. Data sheets on quarantine pests. EPPO Bulletin 35(3): 434-435.

EPPO 2008a. First record of Tuta absoluta in Spain. EPPO Reporting Service 1(001): 2.

EPPO 2008b. First record of Tuta absoluta in Morocco. EPPO Reporting Service 9(174): 2.

EPPO 2009. Tuta absoluta found on Phaseolus vulgaris in Sicilia (IT), EPPO Reporting Service 8(154): 3.

EPPO 2009a. First record of Tuta absoluta in France. EPPO Reporting Service 1(003): 2-3.

EPPO 2009b. First record of Tuta absoluta in Italy. EPPO Reporting Service 2(023): 6.

EPPO 2009d. First record of Tuta absoluta in Tunisia. EPPO Reporting Service 3(042): 2.

EPPO 2009f. First report of Tuta absoluta in Albania. EPPO Reporting Service 9(170): 2.

EPPO 2009g. First report of Tuta absoluta in Portugal. EPPO Reporting Service 9(171): 3.

EPPO 2009h. First record of Tuta absoluta in Malta. EPPO Reporting Service 10(188): 2.

EPPO 2010d. First record of Tuta absoluta in Kosovo. EPPO Reporting Service 11(114): 2. 
Folmer O., Black M., Hoeh W., Lutz R., VRiJenhoek R. 1994. DNA primers for amplification of mitochondrial cytochrome c oxidase subunit I from diverse metazoan invertebrates. Molecular Marine Biology and Biotechnology 3(5): 294-299.

Gotlin ČUlJaK T., Ražov J., Gomboc S., GRUBiŠIĆ D., JURAN I., ŽAnić K. 2010. The first record of tomato leaf miner Tuta absoluta Povolny, 1994 (Lepidoptera: Gelechiidae) in Croatia. Glasilo biljne zaštite 10(4): 273-281. (in Croatian)

Harizanova V., Stoeva A., Mohamedova V. 2009. Tomato leaf miner, Tuta absoluta (Povolny) (Lepidoptera: Gelechiidae) - first record in Bulgaria. Agricultural Science and Technology 1(3): 95-98.

HRNČIĆ S., RADONJIĆ S. 2011. Tuta absoluta MEYRICK (Lepidoptera, Gelechiidae), a new pest in Montenegro. IOBC-WPRS Bulletin 68: 71-74.

KAMBHAMPATI S., Sмith P.T. 1995. PCR primers for amplification of four insect mitochondrial gene fragments. Insect Molecular Biology 4(4): 233-236.

Korycinska A., Moran H. 2009. South American tomato moth Tuta absoluta: plant pest factsheet. Sand Hutton, York, UK.

LEVy D. 2010. Meet the Tuta absoluta. Tomato News 6: 7-10.

OSTRAUSKAS H., IVINSKIS P. 2010. Records of the tomato pinworm (Tuta absoluta (MEYRICK, 1917)) - Lepidoptera: Gelechiidae - in Lithuania. Acta Zoologica Lituanica 20(2): 151-155.

OstoJić I. 2010. Tomato leaf miner (Tuta absoluta) - new pest in Bosnia and Herzegovina. Green Garden 69: 16-17. (in Bosnian)

Simon C., Frati F., Beckenbach A., Crespi B., Liu H., Flook P. 1994. Evolution, weighting, and phylogenetic utility of mitochondrial gene sequences and a compilation of conserved polymerase chain reaction primers. Annals of the Entomological Society of America 87(6): 651-701.

Suinaga F.A., Dias Casali V.W., Picanco M., Foster J. 2004. Genetic divergence among tomato leafminer population based on AFLP analysis. Pesquisa Agropecuária Brasileira 39(7): 645-651.

ŠKALJAC M., KOSTANJŠEK R., ŽANIĆ K. 2012. The presence of Wolbachia in Tuta absoluta (Lepidoptera: Gelechiidae) populations from coastal Croatia and Montenegro. African Entomology 20(1): 191-194.

ToŠEvski I., Jović J., Mitrović M., Cvrković T., Krstić O., KRnJajIĆ S. 2011. Tuta absoluta (MeYrick, 1917) (Lepidoptera, Gelechiidae): a New Pest of Tomato in Serbia. Pesticides and Phytomedicinea 26(3): 197-204.

USDA 2011. New Pest Response Guidelines, Tomato Leafminer (Tuta absoluta), Emergency and Domestic Programs. United States Department of Agriculture. Internet: http://www.aphis.usda. gov/import_export/plants/manuals/emergency/downloads/Tuta-absoluta.pdf

Viggiani G., Filella F., Delrio G., Ramassini W., FoXi C. 2009. Tuta absoluta, a new moth recorded also in Italy. L'Informatore Agrario 2: 66-68. (in Italian)

Received: 5 November 2013

Accepted: 21 March 2014 